\title{
ENVIRONMENTAL IMPACT FROM RIGA CITY LANDFILL, LATVIA
}

Anders Rydergren

SWECO, Stockholm

Sweden

\section{INTRODUCTION}

Getlini waste disposal site has been the major landfill for Riga City since more than 20 years. Due to the conditions at the site and indications on contamination of the groundwater aquifers there were plans to close the site and establish a new landfill. However, those plans were later revised as it was found that the most appropriate alternative would be to remediate the old parts of the disposal site and continue the landfilling operations utilising modern technologies.

Based on this information it was decided to carry out a feasibility study including investigations of the environmental impact from the existing disposal site and propose measures for remediation of existing contamination as well as recommendations on how to continue the operations in an environmentally acceptable way.

The feasibility study was carried out by SWECO, in association with GeoKonsultants in accordance with an agreement with Riga City Council and financed by Sida and Riga City.

\section{BASELINE DATA}

Getlini is situated $15 \mathrm{~km}$ from Riga city centre and $1700 \mathrm{~m}$ from the recipient body, River Daugava which discharges to the Baltic Sea. The total area of the site is 87 hectares of which 35 has been used for waste disposal.

The site is located in a flat area with boggy deposits and it is surrounded by a network of canals discharging the surface water into Daugava. The bog is underlain by quaternary, mainly coarse sediments and further below several aquifers have been identified, named Plavinas, Amata and Gauja, which are not as permeable as the quaternary sediments. 
Annual average precipitation is $627 \mathrm{~mm}$ and both surface water runoff and infiltration are estimated at $100 \mathrm{~mm}$ respectively.

\section{PRESENT ENVIRONMENTAL IMPACT}

The investigations to determine the present environmental impact included several methods such as geophysical methods as well as drilling of observation wells and water sampling of both surface and ground water.

The classification of contamination was based on chloride concentration completed with electrical conductivity, with higher chloride concentration than 300 $\mathrm{mg} / \mathrm{l}$ was classified as contaminated.

It was found that the Quatemary aquifer was contaminated about $2 \mathrm{~km}$ downstream the site, the contamination plume covered an area of $1.5 \mathrm{~km}^{2}$ and the contaminated water volume was estimated at 3 million $\mathrm{m}^{3}$. It was also determined that the contamination was highest in the lower part of the formation. Contamination of deeper aquifers are less well known, but according to water samples from wells in those formations there are no indications of any contamination.

In order to estimate the future contamination plume some hydrogeological modelling was carried out, showing that if no environmental protection measures are taken there will be a massive contamination also in the Plavinas aquifer within some 20 years.

The canals for surface water around the disposal site is heavily polluted. Some of those canals are several meters deep and they might be a main source for pollution of the Quaternary aquifer as they penetrate impermeable layers.

There are two canals around Getlini discharging into River Daugava and they are moderately contaminated at the discharge points.

\section{RECOMMENDATIONS TO REDUCE FUTURE ENVIRONMENTAL IMPACT}

The general objectives of the proposed environmental protection measures are to:

- minimize the generation of leachate

- minimize the discharge of polluted water into surrounding ditches and Daugava

- minimize the infiltration of polluted water into the ground water

- control the extension of the contaminated ground water plume.

The origin of the contamination is infiltration of precipitation into the waste and a base for all other environmental protection measure is to minimize the generation of leachate. This is basically obtained by covering the landfill with lowpermeable soil, thus decreasing the infiltration rate and separation of noncontaminated surface water from leachate by construction of a new duplicate 
system of ditches around the landfill. The cover will furthermore act as a barrier preventing the landfill gas to reach the atmosphere.

The design criterion for the cover is to reduce infiltration to $60 \mathrm{~mm}$ per year and natural materials are proposed to be utilised. The cover will be given a total thickness of $0.5 \mathrm{~m}$ and consist of one layer of $0.3 \mathrm{~m}$ clay with a permeability less than $10^{-9} \mathrm{~m} / \mathrm{s}$ with one $0.2 \mathrm{~m}$ thick layer of gravel, sand or similar on top as protection for the clay.

The existing drainage ditches around the landfill area will in the future be used to collect unpolluted surface water from adjacent areas. Leachate and polluted runoff from uncovered landfill areas is collected through a system of superficial drainage ditches with a bottom level above the ground water level. Some ditches need to be filled up and/or sealed to prevent groundwater from entering into the leachate collection system.

Runoff from the covered areas will be collected through a system of ditches and constructed canals and conveyed to the external surface water ditches.

Two horizontal wells are proposed to be installed in existing canals close to the landfill, each pumped with $5 \mathrm{l} / \mathrm{s}$. This measure will, according to the hydrogeological model, significantly reduce the impact on the groundwater pollution. The wells are designed as gravel-packed subsurface drains conveying the polluted water to a pump sump for further distribution to the treatment plant.

For remediation of the contamination of the Quaternary aquifer 3-4 wells are proposed to be equipped with pumps and the diluted polluted groundwater will be discharged to River Daugava without treatment.

\section{LEACHATE TREATMENT}

The collected leachate will be pumped to a treatment plant before discharged to the recipient. The treatment method proposed is a biological method, Sequence Batch Reactor (SBR). The choice of this treatment method takes into consideration the load that is acceptable to the recipient, River Daugava. The following criteria has been set for reduction of various parameters:

$\begin{array}{ll}\mathrm{BOD}_{7} & 88 \% \\ \text { Total nitrogen } & 25 \% \\ \text { Ammonium-nitrogen } & 90 \% \\ \text { Total phosphorus } & 80 \%\end{array}$

Less polluted waters from some paved areas for waste sorting activities shall be collected and conveyed to settling ponds before discharged to River Daugava via the existing canal system.

Surface runoff from finally covered areas is considered as non polluted and will be connected to nearby surface water ditches without any treatment. 


\section{MONITORING PROGRAMME}

A monitoring programme including 25 wells in the Quaternary aquifer is proposed with sampling once every year. In addition, geo-electrical profiling should be carried out every third year to determine the contour of the contamination plume.

5-10 sampling points for surface water should be considered in the monitoring programme with sampling every year. 